\title{
Liberty University
}

From the SelectedWorks of Steven Alan Samson

1996

\section{Comparative Political Systems}

Steven Alan Samson, Liberty University 
Hardy 10 Office Hours: MWF 8-10, MF 2-3, TH 8-9:30, 2:30-4 Phone: 4551

\section{DESCRIPTION}

A comparative study of the political and governmental systems of selected nations with that of the United States.

\section{REQUIREMENTS}

1. Each student is responsible for assigned readings and should keep a looseleaf notebook of class materials. A separate notebook or folder of reading materials will be kept on reserve on the library, along with a few other resources.

2. Participation is an essential part of class. Reading assignments should be completed before the class meets. Be prepared to discuss textbook material, report on assigned articles (selected from Comparative Politics 96/97), and review current events.

3. Attendance is required. A week's absence may be excused, but lengthy absences or erratic attendance will have a detrimental effect on grades (possibly $10 \%$ of the grade or more). If you expect to miss class, please notify me through the school before class meets.

4. Students will be tested on the lecture, reading, and discussion material through seven quizzes (the lowest score will be dropped) and two essay and short answer exams. Final grade: quizzes $=60 \%$, exams $=40 \%$.

5. Each student will make two brief (10-12 minutes) oral presentations on two countries (each from different continents) in class. Short outlines or abstracts should be provided at the time of presentation. Textbook case study countries are not eligible.

6. Each student will take a pass/fail political geography quiz.

\section{READING LIST}

\section{Textbooks}

Magstadt, Thomas M. Nations and Governments, 2nd ed. [M]

Johnson, Paul. Modern Times, revised edition [J]

\section{Reserve Desk}

Comparative Politics 96/97 [C]

\section{SCHEDULE}

PART ONE: INTRODUCTION; THE AMERICAN SYSTEM (January 14-22)

Required: M. 1-3; J. 1, 18, 19 (pp. 659-74); C. 64; United States Constitution 
Handouts: Ryn, "Cultural Diversity and Renewal;" Estrada, "From El Paso to Plymouth"

Reports: C. $31,32 \& 35,36 \& 38,39,40-41$

PART TWO: WESTERN EUROPE (January 24-29)

Required: M. 4-6; J. 17

Handouts: Kopff, "Commentary on the Gallic Culture War;" Brown, "Regression and Renewal"

Reports: C. $3-4,7-9,10,11,13$ \& 15, 16-17, 20, 22, 26, 28

PART THREE: RUSSIA AND SLAVIC EUROPE (January 31-February 5)

Required: M. 7-9; J. 12 (pp. 429-31), 13, 19 (pp. 674-96)

Handouts: Harrigan, "Allied Crimes Against Humanity;" Fleming, "Ghosts in the Graveyard"

Reports: C. $43,44,45,46,48-49$

POLITICAL GEOGRAPHY QUIZ: February 5

PART FIVE: ASIA (February 7-14)

Required: M. 13-15; J. 14 (pp. 466-480), 16; C. 68

Reports: C. $57,58,59,60$

MIDTERM EXAM: February 10

PART FOUR: THE MIDDLE EAST (February 14-19)

Required: M. 10-12; J. 14 (pp. 480-505); C. 69

PART SIX: SUB-SAHARAN AFRICA (February 21-26)

Required: M. 16-18; J. 15; C. 67

Reports: C. 54,55

PART SEVEN: LATIN AMERICA (February 28-March 5)

Required: M. 19-21

Reports: C. 52,53

FINAL EXAM: March 7 


\section{BIBLIOGRAPHY}

\section{Library}

Almond, Gabriel A., and G. Bingham Powell, Jr. Comparative Politics: A Developmental Approach, 1966.

Balfour, Michael. Germany: The Tides of Power, 1992. 320.943 B185g

Banks, Arthur S., et al., eds. Political Handbook of the World: 1995-1996. R320.02 F771h

Bromley, Simon. Rethinking Middle East politics, 1994. 320.956 B868r

Centemo, Miguel. Democracy within Reason: Technocratic Revolution in Mexico, 1994. 320.972 C $397 d$

Clements, John. Clements' Encyclopedia of World Governments. 1996-1997. R320.403 C626c

Cossolotto, Matthew. The Almanac of European Politics: 1995. R320.02 A445c

Crow, John A. The Epic of Latin America, 1971. 980 C953e [now in 4th ed., 1992] . Italy: A Journey Through Time, 1965. 945 C953i

Culturgram '97. R320.02 C968d

Delury, George E. World Encyclopedia of Political Systems and Parties, 2nd ed., 1987. R320.02 W927d

Department of State. Background Notes. R320.02 D419d

Diamond, Larry, et al., eds. Developing Countries, 1988-1989. 320.91734 D383d

Dudley, William, ed. Middle East: Opposing Viewpoints, 1992. 320.956 M127d

Fischer, David Hackett. Albion's Seed: Four British Folkways in America, 1989. 973.2 F529a

Kraljis, Matthew. The Breakup of Communism, 1993. 320.947 B828k

Krieger, Joel, ed. The New Oxford Companion to the Politics of the World, 1993. R320.03 O98k

Lieven, Anatol. The Baltic Revolution, 1995. 947.4 L722b2

Lipset, Seymour Martin, and Aldo Solari, eds. Elites in Latin America, 1967. $309.18 \mathrm{G} 768 \mathrm{e}$

Naipaul, V.S. India: A Million Mutinies Now, 1990. 915.40452 N157i

Payne, Anthony, and Paul Sutton, eds. Modern Caribbean Politics, 1993. 320.9729 M689p

Paz, Octavio. The Labyrinth of Solitude, 1961 [in Spanish]. 972 P3481

Riding, Alan. Distant Neighbors: A Portrait of the Mexicans, 1985. 972.083 R544d

Rose, Richard. Politics in England. 320.942 R797p

Rosenstock-Huessy, Eugen. Out of Revolution: The Autobiography of Western Man, 1938. 940.2 R815o

Sorokin, Pitirim. The Crisis of Our Age, 1941. 901 S715c1

Thatcher, Margaret. The Downing Street Years.

Thernstrom, Stephan, ed. Harvard Encyclopedia of American Ethnic Groups, 1980. $973.04 \mathrm{~T} 411 \mathrm{~h}$

Walker, Thomas A., ed. Revolution and Counterrevolution in Nicaragua, 1991.

Winters, Paul, ed. Islam: Opposing Viewpoints, 1995. 320.55 I82w 
Other

Almond, Gabriel A., and G. Bingam Powell, Jr. Comparative Politics Today, 1996.

The Anchor Atlas of World History, vol. 2.

Barber, Bernard. Jihad vs. McWorld, 1995.

Brown, Harold O. J. The Sensate Culture, 1996. [on order]

Cahill, Thomas. How the Irish Saved Civilization, 1995. [on order]

Cole, J. P. Geography of World Affairs, 1959.

Crow, John A. Spain: The Root and the Flower, 3rd ed., 1985.

Dehio, Ludwig. The Precarious Balance: Four Centuries of the European Power Struggle, 1962.

Faust, John R., and Judith K. Kornberg. China in World Politics, 1995.

Hall, Edward T. The Silent Language, 1959.

Havel, Vaclav. Summer Meditations, 1992.

Huntford, Roland. The New Totalitarians, revised ed., 1975.

Huntington, Samuel F. The Third Wave, 1991.

Keyes, Charles F., et al. Asian Visions of Authority.

Kirk, Russell. America's British Culture, 1993.

Lieven, Anatol. The Baltic Revolution, 1995.

Lipset, Seymour Martin. The First New Nation, 1963.

Madariaga, Salvador de. Portrait of Europe, 1955.

Malcolm, Noel. Bosnia: A Short History, 1994.

Morris, Robert. Our Globe Under Siege III, 1988.

Naipaul, V. S. The Middle Passage, 1962.

Page, Joseph A. The Brazilians, 1995.

Pritchett, C. Herman. The American Constitutional System.

Prunier, Gerard. The Rwanda Crisis, 1995.

Singer, Max, and Aaron Wildavsky. The Real World Order, 1996.

Skidelsky, Robert. The Road From Serfdom, 1995.

Strausz-Hupe, Robert, et al. Protracted Conflict, 1959.

Thompson, Kenneth W. Fathers of International Thought, 1994. 